\title{
ANALISIS NILAI TAMBAH DAN PEMASARAN SUSU SAPI PADA USAHA SAPI PERAH DI KECAMATAN SELUPU REJANG KABUPATEN REJANG LEBONG
}

\author{
Sri Sugiarti ${ }^{1}$ \\ Sriyoto $^{1}$ \\ Defira Suci Gusfarina ${ }^{2}$ \\ ${ }^{1}$ Staf Pengajar Jurusan Sosial Ekonomi Pertanian Fak. Pertanian UNIB \\ ${ }^{2}$ Alumni Jurusan Sosial Ekonomi Pertanian Fak. Pertanian UNIB
}

\begin{abstract}
The object of this study are : 1) to know the scale of the added value of milkingcow manufacture becomes pasteurize milk and ginger milk instant, 2) to know the kind of marketing channel and margin distribution of milking-cow in Selupu Rejang, Rejang Lebong, Bengkulu Province. This study was done since July until August 2006.The location of this study was determined purposively. The respondents of this study were 23 milking-cow breeder, two collectors in marketing position and two manufacturers. The analysis method of this study is descriptive for general illustration of the location and the kind of marketing channel. Hayami's method was use to analyze quantitative for the added value, margin distribution was counted by the using the cost in the breeders level and the price in the consument's level
\end{abstract}

Keywords: added value, marketing, milking-cow

\section{PENDAHULUAN}

Pembangunan subsektor peternakan merupakan bagian dari pembangunan sektor pertanian yang memiliki nilai strategis, antara lain dalam memenuhi kebutuhan pangan yang terus meningkat akibat bertambahnya jumlah penduduk, peningkatan rata-rata pendapatan penduduk dan penciptaan lapangan pekerjaan. Besarnya potensi sumber daya alam yang dimiliki Indonesia memungkinkan pengembangan subsektor peternakan sehingga menjadi sumber pertumbuhan baru perekonomian Indonesia.

Salah satu jenis usaha peternakan yang potensial untuk terus dipacu perkembangannya adalah usaha ternak sapi perah. Produksi susu segar Indonesia saat ini, sebagian besar (91\%) dihasilkan oleh usaha rakyat atau peternakan rakyat. 
Peternakan rakyat ini memiliki ciri-ciri antara lain keterbatasan modal, skala usaha yang kecil (kepemilikan ternak yang sedikit) dan masih dikelola dengan cara-cara tradisional. Saat ini produksi dalam negeri baru bisa memasok tidak lebih dari 30\% dari permintaan nasional, sisanya $70 \%$ berasal dari impor (Daryanto,2006)

Selanjutnya dalam Daryanto (2006) menyatakan sampai saat ini konsumsi masyarakat Indonesia terhadap produk susu masih sangat rendah 8 liter/kapita/tahun sudah termasuk produk-produk olahan yang mengandung susu. Terlepas dari kondisi tersebut, seiring semakin tingginya pendapatan masyarakat dan semakin bertambahnya jumlah penduduk, dapat dipastikan bahwa konsumsi susu produk Indonesia akan meningkat. Perkiraan peningkatan konsumsi tersebut merupakan peluang yang harus dimanfaatkan dengan baik.

Namun masalah yang dijumpai di lapangan sangat kompleks mulai dari produk susu yang tidak tahan lama sehingga harus diberi penanganan khusus hingga ketika sampai ketangan konsumen produk tersebut dalam keadaan baik. Permasalahan lain yang mendasar bagi petani adalah yang terkait dengan pemasaran. Pemasaran produk pertanian selalu menjadi masalah yang mendasar bagi petani. Padahal aspek pemasaran merupakan salah satu faktor penting dalam pengembangan hasil-hasil pertanian. Peternak seringkali mengalami kerugian akibat tidak terjualnya atau tersalurnya susu sapi yang dihasilkan sehingga pakan yang dibelipun tidak memadai dan perkembangan usahanya pun terhambat. Dengan adanya masalah tersebut peternak membutuhkan pasar yang berfungsi dengan baik sehingga mampu menghubungkan produsen dan konsumen, sehingga interaksi pasar yang terjadi akan memungkinkan untuk memperbaiki penghidupan peternak dengan mengarahkan produk susu mereka dapat memenuhi permintaan pasar. 
Revolusi putih sebagai gagasan pencarian solusi, bertujuan meningkatkan produksi dan meningkatkan konsumsi susu nasional salah satunya dengan pengembangan beragam industri pengolahan susu atau agroindustri susu sehingga harga ditingkat peternak menjadi relatif lebih stabil. Susu selain dapat dikonsumsi dalam bentuk segar, dapat pula diolah terlebih dahulu menjadi susu olahan. Konsumsi masyarakat akan susu olahan jauh lebih besar dibandingkan dengan konsumsi susu segar. Agroindustri bukan saja dilakukan oleh industri-industri pengolahan susu tetapi juga industri rumah tangga. Pengolahan susu yang dilakukan oleh rumah tangga peternak akan memberikan nilai tambah yang besar bagi usaha sapi perahnya.

Sentra pengembangan usaha ternak sapi perah di Propinsi Bengkulu adalah di Kabupaten Rejang Lebong, Kecamatan Selupu Rejang. Usaha ini merupakan program pemerintah yang dimulai pada tahun 2002. Awalnya peternak di daerah ini tergabung dalam tiga koperasi di tiga desa, yaitu Kelompok Tani Usaha di Desa Air Duku, Kelompok Tani Setaria di Desa Sambirejo dan Kelompok Tani Mulya di Desa APK Bandung dengan produksi total per hari rata-rata 380 liter dari 34 orang peternak (Laporan Ditnak,2003). Namun setahun setelah itu peternakan sapi perah di Desa Sambirejo perlahan mulai surut hingga sekarang ini tidak ada sama sekali. Pada sapi perah yang ada tidak pernah dilakukan pemerahan, hanya dipelihara untuk penggemukan. Hal ini terjadi karena produksi sapi perah yang produksinya cukup tinggi terhambat pada pemasaran dimana pada saat itu Industri Pengolah Susu (IPS) yang ada hanya satu dan susu yang dapat ditampung sebanyak 200 liter per harinya. Sehingga pasar menjadi tidak efisien dimana hanya ada satu pembeli atau lembaga pengolah.

Pada saat ini untuk mengatasi masalah pemasaran telah ada 2 Industri Pengolah Susu (IPS) dalam skala kecil, dan diharapkan mampu menampung hasil produksi susu sapi perah dari peternak di dua desa dan pasar pun menjadi lebih efisien. Industri 
Pengolah Susu ini masih menggunakan teknologi yang sederhana untuk menjadi berbagai macam produk diantaranya susu segar, dodol, karamel, yoghurt, kerupuk susu dan sebagainya. Produk dari IPS ini dipasarkan ke berbagai kota seperti Lubuk Linggau, Kepahiang, dan Bengkulu melalui pedagang pengecer yang tersebar di daerah-daerah pemasaran tersebut. Oleh karena itu produk olahan ini merupakan usaha atau kegiatan yang menarik untuk diteliti baik nilai tambah maupun pemasarannya.

\section{METODOLOGI PENELITIAN}

Pemilihan lokasi penelitian ini dilakukan secara sengaja (purposive) yaitu di dua desa Kecamatan Selupu Rejang, yaitu di Desa Air Duku dan Desa APK Bandung dengan pertimbangan di kedua desa tersebut terdapat masyarakat dalam wadah kelompok tani yang mengusahakan peternakan sapi perah. Pengolahan lebih lanjut berupa susu pasteurisasi dan instan susu jahe dari susu sapi perah yang dihasilkan, dilakukan oleh industri pengolahan yang berada tidak jauh dari lokasi peternakan.

Responden dalam penelitian ini adalah peternak sapi perah di Desa Air Duku dan Desa APK Bandung, Kecamatan Selupu Rejang. Pengambilan responden peternak dilakukan dengan menggunakan metode sensus, dimana seluruh populasi peternak sapi perah diambil sebagai responden. Dari data diperoleh jumlah peternak di kedua desa adalah 23 orang dengan perincian 12 orang di Desa Air Duku dan 11 orang di Desa APK Bandung. Responden lembaga pengolah diambil keseluruhan dari lembaga pengolahan (metode sensus) dalam penelitian ini adalah pengusaha pengolah susu menjadi berbagai produk olahan dari susu yang diambil dari peternak sapi perah di Desa Air Duku dan di Desa APK Bandung Kecamatan Selupu Rejang. Responden kegiatan pemasaran juga ditentukan dengan sensus yaitu mereka yang terlibat dalam pemasaran susu sapi baik itu susu sapi yang telah diolah maupun susu murni. 
Analisis data dilakukan dengan dua cara yaitu analisis deskriptif dan analisis kuantitatif. Analisis deskriptif dilakukan untuk melihat gambaran umum dan khusus dari lokasi dan saluran pemasaran. Analisis kuantitatif untuk melihat besarnya keuntungan dan nilai tambah, melalui analisis margin pemasaran akan dilihat efisiensi pemasaran.

Format analisis keuntungan dan nilai tambah menurut Hayami dalam Tomi (2004) adalah :

\section{Hasil produksi, bahan baku, harga}

1. Hasil produksi $(\mathrm{kg})$

2. Bahan baku (kg) a

3. Input tenaga kerja $(\mathrm{HOK})$---

4. Faktor Konversi (1)/(2) -

5. Koefisien tenaga kerja (3)/(2) -- c/b=e

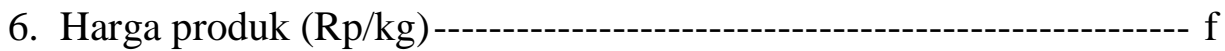

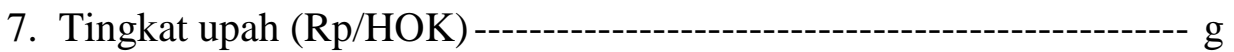

\section{Pendapatan dan Keuntungan}

8. Harga bahan baku (Rp/kg) ---

9. Sumbangan bahan lain (Rp/kg bahan baku) --------------- i

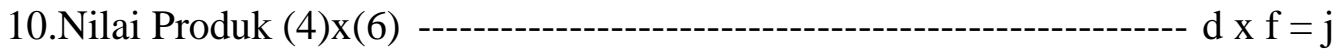

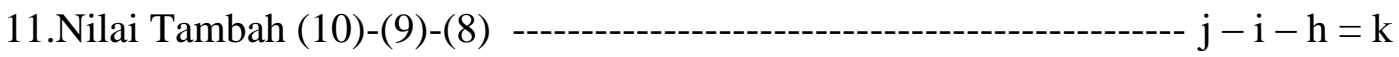
1

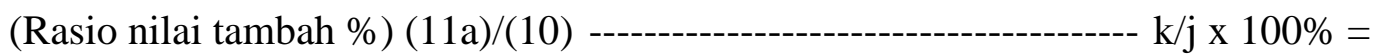

12.Pendapatan tk (5)x(7) -

$($ Pendapatan tk \%)(12a)/(11) ------- m/k x 100\% $=\mathrm{n}$

13.Keuntungan (11a) - (12a) --- $\mathrm{k}-\mathrm{m}=\mathrm{o}$

(Tingkat keuntungan \%) (13)/(10) ----------------------------------- o/k x 100\%= $\mathrm{p}$

Untuk mengetahui bagaimana bentuk saluran pemasaran yang terjadi pada pemasaran susu sapi perah, akan dianalisis secara deskriptif yaitu menggambarkan pola saluran pemasaran susu daerah penelitian berdasarkan alur pemasaran dari produsen sampai ke konsumen akhir. 
Pf = Harga pada tingkat produsen Untuk menghitung marjin pemasaran adalah sebagai berikut :

$$
\begin{aligned}
& \mathrm{Mji}=p s i-p b i \\
& M j i=C i+\pi i \\
& \pi \mathrm{i}=\mathrm{Mji}-\mathrm{Ci}
\end{aligned}
$$

Total marjin pemasaran adalah :

$$
M j=\sum_{i=1}^{n} M j i
$$

Dengan harga ditingkat konsumen secara matematis dapat ditulis :

$$
\begin{aligned}
& \operatorname{Pr}=\operatorname{Pf}+\mathrm{Mj} \\
& \mathrm{Mj}=\operatorname{Pr}-\mathrm{Pf}
\end{aligned}
$$

Dimana : Mji = Marjin pemasaran pada lembaga pemasaran tingkat ke $\mathrm{i}$

$$
\begin{aligned}
& \mathrm{Psi}=\text { Harga jual pemasaran tingkat ke } \mathrm{i} \\
& \mathrm{Pbi}=\text { Harga beli tingkat ke } \mathrm{i} \\
& \mathrm{Ci}=\text { Biaya pemasaran lembaga pemasaran tingkat ke } \mathrm{i} \\
& \pi \mathrm{i}=\text { Keuntungan pemasaran ke } \mathrm{i} \\
& \mathrm{i} \quad=1,2,3 \ldots . . \\
& \mathrm{Mj}=\text { Total marjin pemasaran } \\
& \mathrm{Pr}=\text { Harga pada tingkat konsumen }
\end{aligned}
$$

\section{HASIL DAN PEMBAHASAN}

\section{Analisis Nilai Tambah}

Analisis nilai tambah proses pengolahan susu menjadi susu pasteurisasi dan instan susu jahe pada tahapan proses yang dilakukan lembaga pengolah di Kecamatan Selupu Rejang pada Agustus 2006. Perhitungan nilai tambah ini dilakukan dengan metode rata-rata dari 2 lembaga pengolah. Input yang digunakan untuk memproduksi susu pasteurisasi selain susu murni adalah gula dan pasta sedangkan untuk instan susu jahe adalah susu murni dan input lainnya adalah jahe dan gula. Peralatan yang diperlukan untuk mengolah susu pasteurisasi adalah peralatan pasteurisasi, tempat mencampurkan pasta, pengaduk, timbangan,sealer, kemasan, merk dan freezer untuk penyimpanan. Sedangkan peralatan untuk instan susu jahe adalah kuali, parutan, saringan, pisau dan blender atau penggilingan. Bahan baku yang digunakan diperoleh 
dengan membeli dari peternak atau kelompok tani di Kecamatan Selupu Rejang. Analisis nilai tambah susu sapi perah menjadi susu pasteurisasi dan instan susu jahe rata-rata dari dua industri pengolah dapat dilihat pada Tabel 1 dan 2.

Tabel 1. Analisis Nilai Tambah Susu Sapi Perah Menjadi Susu Pasteurisasi

\begin{tabular}{lrrr}
\hline \multicolumn{1}{c}{ Variabel } & Pengolah I & Pengolah II & Rata-rata \\
\hline Hasil produksi, bahan baku, harga & & & \\
1. Hasil produksi (liter) & 115,00 & 91,00 & 103,00 \\
2. Bahan baku (liter) & 115,00 & 91,00 & 103,00 \\
3. Input tenaga kerja (HOK) & 3,12 & 1,25 & 1,25 \\
4. Faktor konversi & 1,00 & 1,00 & 1,00 \\
5. Koefisien tk (HOK/liter bahan baku) & 0,03 & 0,01 & 0,02 \\
6. Harga produk (Rp/liter) & $5.769,23$ & $8.000,00$ & $6.884,62$ \\
7. Tingkat upah (Rp/HOK) & $8.333,33$ & $10.000,00$ & $9.166,67$ \\
Pendapatan dan Keuntungan & & & \\
8. Harga bahan baku (Rp/liter) & $1.600,00$ & $1.600,00$ & $1.600,00$ \\
9. Bahan lain (Rp/liter bahan baku) & $1.111,48$ & $1.559,40$ & $1.335,44$ \\
10.Nilai Produk (Rp/liter bahan baku) & $5.769,23$ & $8.000,00$ & $6.884,62$ \\
11.Nilai Tambah (Rp/liter bahan baku) & $3.057,75$ & $4.840,60$ & $3.949,18$ \\
$\quad$ Rasio nilai tambah (\%) & 53,00 & 60,51 & 56,76 \\
12.Pendapatan tk (Rp/liter bahan baku) & 250,00 & 100,00 & 175,00 \\
$\quad$ Pendapatan tk (\%) & 8,18 & 2,07 & 5,12 \\
13.Keuntungan (Rp/liter bahan baku) & $2.807,75$ & 4740,60 & $3.774,18$ \\
Tingkat keuntungan (\%) & 91,82 & 97,93 & 94,88 \\
\hline Sumber : Data pilmer & & &
\end{tabular}

Sumber : Data primer diolah September 2006

Dari Tabel 1 terlihat, pada pengolahan susu sapi menjadi susu oleh 2 industri pengolahan dilakukan setiap hari dengan rata-rata penggunaan bahan baku susu sapi perah setiap kali proses produksi adalah 103 liter dan menghasilkan susu pasteurisasi sebanyak 103 liter, sehingga diperoleh faktor konversi sebesar 1 artinya setiap liter bahan baku susu murni akan menghasilkan satu liter susu pasteurisasi. Dari 2 pengolah, pengolah I paling banyak melakukan produksi, hal ini disebabkan karena lokasi tempat pengolahan berada di ibukota Kabupaten sehingga lebih banyak terdapat konsumen sedangkan lokasi pengolahan II berada di ibukota Kecamatan, selain itu jaringan pemasaran dari pengolah I jauh lebih luas. Untuk kegiatan pengolahan ini digunakan 
tenaga kerja sebanyak 2,18 HOK, dengan upah rata-rata per HOK sebesar Rp 9.166,67. Perbedaan tingkat upah antar pengolah I $(\operatorname{Rp} 8.333,33)$ dan pengolah II $(\operatorname{Rp} 10.000,00)$ dikarenakan perbedaan sistem pembayaran, pada pengolah I pembayaran upah dilakukan per bulan sedangkan pada pengolah II pembayaran dilakukan per hari. Tenaga kerja pada pengolah II tidak terikat pada lembaga pengolahan, sehingga yang bekerja setiap hari bisa berganti, sedangkan pada pengolah I tenaga kerjanya terikat. Jumlah HOK yang digunakan sebanyak 2,18 HOK setelah dibagi dengan jumlah bahan baku yang digunakan diperoleh koefisien tenaga kerja sebesar 0,02. Koefisien tenaga kerja ini merupakan banyaknya tenaga kerja yang digunakan dalam satuan HOK untuk mengolah satu liter bahan baku. Dari nilai koefisien tenaga kerja yang diperoleh dapat diartikan untuk mengolah satu liter bahan baku susu sapi membutuhkan tenaga kerja sebanyak 0,02 HOK. Harga bahan baku susu murni yang digunakan yaitu Rp 1.600,00/liter. Sementara itu sumbangan bahan lain yang digunakan dalam kegiatan pengolahan ini pada pengolah I adalah sebesar Rp 1.111,48 dan pengolah II sebesar Rp 1.559,40 sehingga rata-rata dari kedua pengolah diperoleh Rp 1.335,44 untuk setiap liter bahan baku. Bahan lain ini terdiri dari beberapa komponen yaitu bahan penolong seperti gula dan pasta serta kemasan. Perbedaan dari biaya untuk bahan lain disebabkan oleh adanya perbedaan kemasan. Pada pengolah II selain kualitas kemasan yang lebih baik, juga memerlukan tambahan bahan lain untuk penjualan yaitu pipet dan tusuk gigi, sedangkan pada pengolah I untuk mengkonsumsinya tidak memerlukan pipet dan tusuk gigi. Untuk bahan lain yang digunakan yaitu gula dan pasta sama. Dari hasil perkalian faktor konversi dengan harga output diperoleh nilai produk dari susu pasteurisasi ini sebesar Rp 6.884,62, artinya nilai susu pasteurisasi yang dihasilkan dari satu liter bahan baku susu murni adalah $\mathrm{Rp} 6.884,62$. Disini terlihat nilai produk susu pasteurisasi yang dihasilkan dalam kegiatan pengolahan ini lebih besar dibandingkan dengan harga satu 
liter bahan baku yang membentuknya. Nilai produk yang perbedaanya cukup besar antara pengolah I yaitu Rp 5.769,23 dan pengolah II Rp 8.000,00 disebabkan perbedaan harga produk antara pengolah I dan II. Perbedaan harga yang terjadi disebabkan karena adanya perbedaan kemasan sehingga isi dalam kemasan volumenya pun berbeda. Pengolah I volume per kemasan adalah 65 ml sedangkan pengolah II 240 ml. Kemasan pengolah I lebih ekonomis sehingga segmen konsumennya pun lebih luas. Nilai tambah yang diciptakan dari kegiatan pengolahan susu sapi murni menjadi susu pasteurisasi diperoleh dengan mengurangkan nilai produk yang telah diketahui sebelumnya, yaitu sebesar Rp 6.884,62 dengan bahan baku dan sumbangan bahan lain yang besarnya masing-masing $\mathrm{Rp} 1.600,00$ dan $\mathrm{Rp} 1.335,44$, maka didapat nilai tambah yang tercipta yaitu sebesar Rp 3.949,18. Rasio nilai tambah pada pengolahan susu sapi menjadi susu pasteurisasi ini sebesar 56,76 \%. Hasil dalam penelitian ini jauh lebih besar dari hasil penelitian Tomi pada tahun 2003 dimana nilai tambah yang diperoleh adalah sebesar Rp 865,73 dan rasio nilai tambah yang dihasilkan adalah 29,63\%. Hal ini disebabkan karena adanya perubahan teknologi dengan penggunaan mesin pasteurisasi dan adanya perubahan kemasan dari produk sehingga yang mengakibatkan volume berubah dan dapat mengoptimalkan produksi sehingga keuntungan yang diterima pun mencapai optimal. Upah tenaga kerja yang dikeluarkan pada kegiatan pengolahan ini sebesar Rp 9.166,67 per HOK. Persentase upah tenaga kerja ini terhadap nilai tambah yang tercipta adalah sebesar 5,12\%. Sementara keuntungan yang diperoleh dari kegiatan pengolahan ini adalah sebesar Rp 3.774,18 yang artinya untuk setiap pengolahan satu liter bahan baku susu sapi murni menjadi susu pasteurisasi, industri pengolah memperoleh keuntungan sebesar Rp 3.774,18.

Tabel 2. Analisis Nilai Tambah Susu Sapi Perah Menjadi Instan Susu Jahe

\begin{tabular}{crrr}
\hline Variabel & Pengolah I & Pengolah II & Rata-rata \\
\hline Hasil produksi, bahan baku, harga & 5,00 & 5,00 & 5,00 \\
\hline
\end{tabular}




\begin{tabular}{lrrr}
\hline 1. Hasil produksi (kg) & 10,00 & 10,00 & 10,00 \\
2. Bahan baku (liter) & 0,75 & 0,75 & 0,75 \\
3. Input tenaga kerja (HOK) & 0,50 & 0,50 & 0,50 \\
4. Faktor konversi & 0,08 & 0,08 & 0,08 \\
5. Koefisien tk (HOK/liter bahan baku) & $36.000,00$ & $36.000,00$ & $36.000,00$ \\
6. Harga produk (Rp/liter) & $23.333,33$ & $25.000,00$ & $24.166,67$ \\
7. Tingkat upah (Rp/HOK) & $1.600,00$ & $1.600,00$ & $1.600,00$ \\
Pendapatan dan Keuntungan & $3.715,00$ & $3.560,00$ & $3.637,50$ \\
8. Harga bahan baku (Rp/liter) & $18.000,00$ & $18.000,00$ & $18.000,00$ \\
9. Bahan lain (Rp/liter bahan baku) & $12.685,00$ & $12.840,00$ & $12.762,50$ \\
10.Nilai Produk (Rp/liter bahan baku) & 70,47 & 71,33 & 70,90 \\
11.Nilai Tambah (Rp/liter bahan baku) & $1.866,67$ & $2.000,00$ & $1.933,34$ \\
$\quad$ Rasio nilai tambah (\%) & 14,72 & 15,58 & 15,15 \\
12.Pendapatan tk (Rp/liter bahan baku) & $10.818,33$ & $10.840,00$ & $10.829,16$ \\
$\quad$ Pendapatan tk (\%) & 85,28 & 84,42 & 84,85 \\
13.Keuntungan (Rp/liter bahan baku) & & & \\
Tingkat keuntungan (\%) & & & \\
\hline Sum : Data primer diolah September & & & \\
\hline
\end{tabular}

Sumber : Data primer diolah September 2006

Untuk pengolahan susu sapi menjadi instan susu jahe, dari Tabel 8 terlihat bahwa rata-rata bahan baku yang digunakan dalam satu kali proses produksi adalah 10,00 liter. Pengolahan bahan baku 10,00 liter susu sapi menghasilkan instan susu jahe sebesar $5 \mathrm{~kg}$. Faktor konversi untuk kegiatan pengolahan ini adalah 0,50 yang artinya setiap liter bahan baku yang digunakan dalam proses produksi akan menghasilkan 0,50 kg instan susu jahe. Tenaga kerja yang digunakan untuk kegiatan pengolahan ini sebanyak 0,75 HOK, sementara upah yang dibayarkan sebesar Rp 24.166,67/HOK. Tingkat upah yang terjadi antara pengolah I dan pengolah II berbeda, hal ini disebabkan pada pengolah I upah yang diterima tenaga kerja setiap mengolah instan susu jahe Rp 15.000,00 ditambahkan dengan upah bulanan yang diterima sebagai tenaga kerja pengolah susu yang jika dihitung per harinya adalah sebesar Rp 8.333,33 sehingga per HOK diperoleh upah sebesar Rp 23.333,33. Sedangkan pada pengolah II setiap pengolahan instan susu jahe tenaga kerja memperoleh upah Rp 25.000,00 yang diberikan langsung setelah pekerjaannya selesai. Setelah dihitung, didapat nilai 
koefisien tenaga kerja sebesar 0,08 yang dapat diartikan untuk pengolahan satu liter bahan baku susu sapi murni menjadi instan susu jahe digunakan tenaga kerja sebanyak 0,08 HOK. Harga bahan baku susu sapi yang digunakan dalam produksi instan susu jahe sama dengan produksi susu pasteurisasi yaitu Rp 1.600,00/liter. Untuk bahan lain yang digunakan dalam proses produksi instan susu jahe ini yaitu gula, jahe dan kemasan yang besarnya adalah Rp 3.637,50. Dari tabel diketahui nilai produk instan susu jahe yang dihasilkan ini sebesar Rp 18.000,00 yang diperoleh dari perkalian faktor konversi dengan harga output. Harga output atau harga instan susu jahe adalah Rp 36.000,00 per kg. Arti dari nilai produk yang diperoleh ini adalah nilai instan susu jahe yang dihasilkan dari satu liter bahan baku susu sapi adalah Rp 18.000,00. Sedangkan nilai tambah yang tercipta dari kegiatan pengolahan ini adalah $\mathrm{Rp} 12.762,50$, hasil ini hampir sama besarnya dengan nilai tambah produk instan jahe tanpa susu dalam Efriani (2003) yaitu Rp 13.944,23. Rasio nilai tambah terhadap nilai produk sebesar 70,90\%. Imbalan tenaga kerja yang dikeluarkan pada proses pengolahan susu menjadi instan susu jahe ini sebesar Rp 1.933,34 dengan persentase nilai imbalan tenaga kerja sebesar $15,15 \%$. Keuntungan yang diperoleh pada kegiatan pengolahan ini untuk satu liter bahan baku yang digunakan adalah Rp 10.829,16 dengan tingkat keuntungan sebesar 84,85 \%. Nilai tambah untuk Instan Susu Jahe lebih besar dari pada Susu Pasteurisasi dikarenakan nilai produk dari Instan Susu Jahe jauh lebih besar dari nilai produk Susu Pasteurisasi. Tingkat keuntungan susu pasteurisasi lebih tinggi dari instan susu jahe serta konsumsi susu pasteurisasi lebih tinggi dari instan susu jahe. Pengolah akan meningkatkan keuntungan bukan dari nilai produk yang lebih tinggi melainkan dari penjualan yang lebih banyak. Selain itu menurut Zakaria (2000) interaksi antara tingkat teknologi, manajemen usaha dan kualitas sumber daya manusia pengelola akan 
menentukan tingkat produksi dan pendapatan yang pada akhirnya akan menentukan besarnya nilai tambah yang dihasilkan.

\section{Analisis Pemasaran}

Saluran pemasaran merupakan saluran yang digunakan oleh produsen untuk menyalurkan produknya kepada konsumen. Dari hasil penelitian, saluran pemasaran susu sapi yang dihasilkan peternak sapi perah dapat dilihat pada Gambar 1.

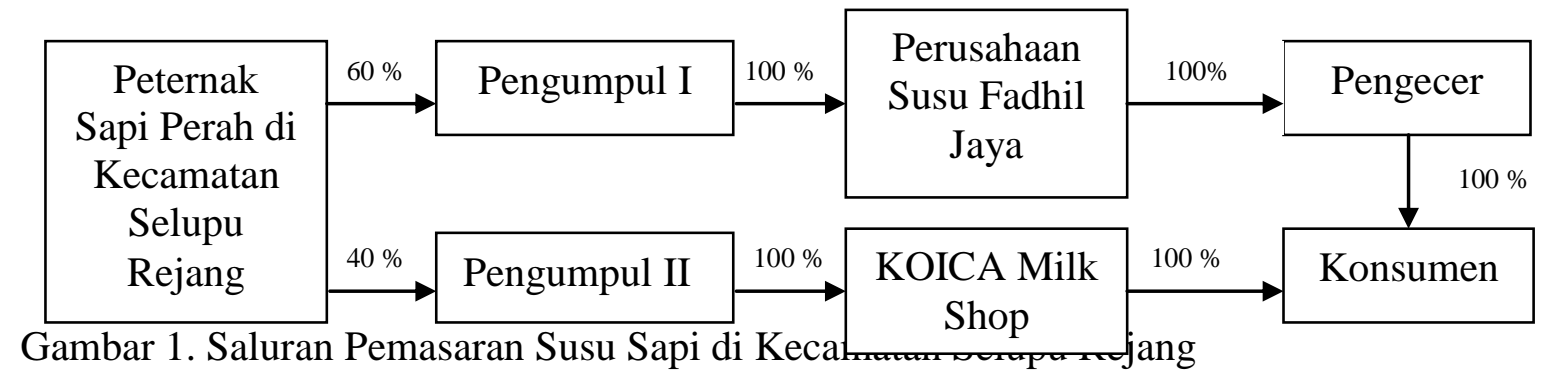

Di Kecamatan Selupu Rejang peternakan sapi perah saat ini terdapat di 2 desa yaitu Desa Air Duku dan Desa APK Bandung yang rata-rata jumlah produksi yang dijual perhari adalah 250 liter. Dari Gambar 4 diatas dapat dilihat peternak produsen di Kecamatan Selupu Rejang menjual hasil produksi susu perahnya ke pedagang pengumpul I sebanyak 150 liter yang kemudian menjualnya ke Perusahaan pengolah Fadhil Jaya yang disebut saluran I sedangkan dan 100 liter dijual ke pedagang pengumpul II dan selanjutnya menjualnya ke pengolah KOICA Milk Shop disebut saluran II. Perusahaan Fadhil Jaya merupakan Industri Pengolah Susu (IPS) yang mempunyai beberapa pengecer yang tersebar di Lubuk Linggau, Curup, Kepahyang, Bengkulu Utara dan Kota Bengkulu. KOICA Milk Shop adalah Industri Pengolah Susu (IPS) yang langsung menjual hasil produksinya di KOICA Milk Shop, KOICA Milk Shop pernah mencoba memasarkan produknya ke kota Bengkulu, namun karena jauh dan penanganan dalam perjalan kurang sehingga ketika susu sampai di Bengkulu menjadi rusak.

Tabel 3. Analisis Marjin Pemasaran Susu Pasteurisasi di Kecamatan Selupu Rejang. 


\begin{tabular}{|c|c|c|c|c|c|}
\hline \multirow[t]{2}{*}{ No } & \multirow[b]{2}{*}{ Uraian } & \multicolumn{2}{|c|}{ Saluran I } & \multicolumn{2}{|c|}{ Saluran II } \\
\hline & & $\begin{array}{c}\text { Jumlah } \\
(\mathrm{Rp})\end{array}$ & $\begin{array}{l}\text { Persentase } \\
(\%)\end{array}$ & $\begin{array}{l}\text { Jumlah } \\
\text { (Rp) }\end{array}$ & $\begin{array}{l}\text { Persentase } \\
(\%)\end{array}$ \\
\hline 1 & $\begin{array}{l}\text { Peternak sapi perah } \\
\text { a. Harga jual }\end{array}$ & $1.400,00$ & 18,20 & $1.400,00$ & 17,50 \\
\hline 2 & $\begin{array}{l}\text { Pedagang pengumpul } \\
\text { a. Harga beli } \\
\text { b. Biaya pemasaran }\end{array}$ & $1.400,00$ & & $1.400,00$ & \\
\hline & - Biaya transportasi & 0,00 & 0,00 & 20,00 & 0,25 \\
\hline & - Biaya peny alat & 0,29 & 0,01 & 0,33 & 0,00 \\
\hline & c. Harga jual & $1.600,00$ & 20,87 & $1.600,00$ & 20,00 \\
\hline & d. Marjin & 200,00 & 2,60 & 200,00 & 2,50 \\
\hline & e. Keuntungan & 159,71 & 2,08 & 179,67 & 2,25 \\
\hline 3 & $\begin{array}{l}\text { Industri Pengolah } \\
\text { a. Harga beli } \\
\text { b. Biaya pemasaran }\end{array}$ & $1.600,00$ & 20,87 & $1.600,00$ & 20,00 \\
\hline & - Biaya pengolahan & $3.138,72$ & 40,81 & $3.877,820,00$ & 48,47 \\
\hline & - Biaya transportasi & 40,00 & 0,52 & $8.000,00$ & 0,00 \\
\hline & c. Harga jual & $5.769,00$ & & $6.400,00$ & \\
\hline & d. Marjin & $4.169,00$ & 54,20 & $2.522,18$ & 80,00 \\
\hline & e. Keuntungan & 990,28 & 19,16 & & 31,53 \\
\hline 4 & $\begin{array}{l}\text { Pedagang pengecer } \\
\text { a. Harga beli }\end{array}$ & $5.769,00$ & & & \\
\hline & $\begin{array}{l}\text { b. Biaya pemasaran } \\
-\quad \text { Biaya transportasi }\end{array}$ & 40,00 & 0,52 & & \\
\hline & c. Harga jual & $7.692,00$ & 25,00 & & \\
\hline & d. Marjin & $1.923,00$ & 24,50 & & \\
\hline & e. keuntungan & $1.883,00$ & & & \\
\hline & Total Marjin & $6.292,00$ & & $6.600,00$ & \\
\hline & Total Keuntungan & $3.032,99$ & & $2.701,85$ & \\
\hline
\end{tabular}

Sumber : Data Primer Diolah September 2006

Keterangan : persentase diperoleh dari perbandingan harga yang diterima oleh konsumen.

Dari Tabel 3 dapat diketahui bahwa peternak sapi perah menjual susu sapi yang dihasilkannya ke pedagang pengumpul dengan harga Rp1.400,00/liter. Sementara itu pedagang pengumpul menjual ke pengolah dengan harga Rp 1.600/liter. Biaya pemasaran yang dikeluarkan oleh pedagang pengumpul I hanya biaya penyusutan peralatan sebesar Rp 0,29/liter sedangkan biaya transportasi ditanggung oleh industri pengolah. Untuk pedagang pengumpul II biaya peyusutan peralatan sebesar Rp 0,33/liter dan biaya trasnportasi sebesar Rp 20,00/liter. Total marjin pemasaran yang diperoleh oleh pedagang pengumpul adalah Rp 200,00/liter dan setelah dikurangi dengan biaya pemasaran yang dikeluarkan maka pedagang pengumpul I memperoleh keuntungan sebesar Rp 199,71/liter sedangkan pengumpul II Rp 179,67/liter dari susu 
yang dipasarkan ke pengolah. Sementara itu pengolah I yang menjual produknya ke pengecer seharga Rp 5.769,00/liter dengan biaya pemasaran sebesar Rp 3.138,72/liter yang terdiri dari biaya transportasi $\mathrm{Rp}$ 40,00/liter dan biaya pengolahan sebesar $\mathrm{Rp}$ 3.138,72/liter dan marjin yang diperoleh oleh industri pengolah sebesar Rp 4.169,00/liter, setelah dikurangi biaya pemasaran keuntungan yang diterima industri pengolah sebesar Rp 990,28/liter. Pengolah II yang langsung menjual produknya seharga Rp 8.000,00/liter dengan biaya pemasaran yang hanya dikeluarkan untuk pengolahan adalah sebesar Rp 3.877,82/liter dan marjin yang terjadi adalah $\quad$ Rp 6.400,00, jika dikurangi dengan biaya pemasaran yang dikeluarkan maka keuntungan yang diterima industri pengolah pada saluran II adalah sebesar Rp 2.522,18. Pada saluran II ditingkat pedagang pengecer di Curup biaya pemasaran yang dikeluarkan hanya untuk transportasi dalam kota sebesar Rp 40/liter. Dengan harga jual susu per liternya sebesar Rp 7.692,00 dengan harga beli Rp 5.769,00/liter, maka marjin yang diperoleh pedagang pengecer adalah Rp 1.923,00/liter. Setelah dikurangi biaya pemasaran maka keuntungan yang diperoleh adalah Rp 1.883,00 per liter susu yang dijual. Berdasarkan total marjin pemasaran yang terjadi, saluran II memiliki marjin yang lebih besar yaitu $82,50 \%$ dari harga yang diterima konsumen, dibandingkan pada saluran I yaitu $81,80 \%$ dari harga jual yang diterima konsumen. Perbedaan total marjin pemasaran dikarenakan pada saluran II harga yang diberikan kepada konsumen jauh lebih besar. Walaupun pada saluran I rantai pemasarannya lebih panjang tapi tidak berpengaruh meningkatkan marjin pemasaran.

Dari analisis marjin juga dapat dikatakan bahwa sistim pemasaran susu pasteurisasi dapat dikatakan tidak efisien. Hal ini ditunjukkan dengan besarnya marjin pemasaran dan tidak meratanya keuntungan yang diambil oleh masing-masing lembaga pemasaran serta lebih kecilnya bagian yang diterima peternak dibandingkan lembaga 
pemasaran lainnya. Bagian terbesar diterima oleh lembaga pengolahan yaitu sebesar $54,20 \%$ pada saluran I dan sebesar $80 \%$ pada saluran II hal ini disebabkan biaya yang dikeluarkan untuk pengolahan yang cukup besar. Besarnya bagian yang diterima peternak pada saluran I adalah 18,20 \% dari harga yang dibayar konsumen dan pada saluran II sebesar 17,50 \% dari harga yang dibayar konsumen. Perbedaan besarnya bagian harga yang diterima peternak terhadap harga yang dibayar konsumen pada saluran I dan II, tidak berpengaruh terhadap nilai nominal yang diterima peternak karena harga jual yang diterima peternak dari kedua saluran pemasaran tersebut sama.

Tabel 4. Analisis Marjin Pemasaran Instan Susu Jahe di Kecamatan Selupu Rejang.

\begin{tabular}{|c|c|c|c|c|c|}
\hline \multirow[t]{2}{*}{ No } & \multirow[b]{2}{*}{ Uraian } & \multicolumn{2}{|c|}{ Saluran I } & \multicolumn{2}{|c|}{ Saluran II } \\
\hline & & $\begin{array}{l}\text { Jumlah } \\
\text { (Rp) }\end{array}$ & $\begin{array}{l}\text { Persentase } \\
(\%)\end{array}$ & $\begin{array}{l}\text { Jumlah } \\
\text { (Rp) }\end{array}$ & $\begin{array}{l}\text { Persentase } \\
(\%)\end{array}$ \\
\hline 1 & $\begin{array}{l}\text { Peternak sapi perah } \\
\text { a. Harga jual }\end{array}$ & $1.400,00$ & 3,89 & $1.400,00$ & 3,89 \\
\hline 2 & $\begin{array}{l}\text { Pedagang pengumpul } \\
\text { a. Harga beli } \\
\text { b. Biava pemasaran }\end{array}$ & $1.400,00$ & & $1.400,00$ & \\
\hline & - Biaya transportasi & 0,00 & 0,00 & 20,00 & 0,06 \\
\hline & - Biaya peny alat & 0,29 & 0,00 & 0,33 & 0,00 \\
\hline & c. Harga jual & $1.600,00$ & 4,44 & $1.600,00$ & 4,44 \\
\hline & d. Marjin & 200,00 & 0,56 & 200,00 & 0,56 \\
\hline & e. Keuntungan & 159,71 & 0,44 & 179,67 & 0,50 \\
\hline 3 & $\begin{array}{l}\text { Industri Pengolah } \\
\text { a. Harga beli } \\
\text { b. Biaya pemasaran }\end{array}$ & $1.600,00$ & 4,44 & $1.600,00$ & 4,44 \\
\hline & - Biaya pengolahan & $10.952,68$ & 30,42 & $10.286,15$ & 28,57 \\
\hline & - Biaya transportasi & 40,00 & 0,11 & 0,00 & 0,00 \\
\hline & c. Harga jual & $36.000,00$ & & $36.000,00$ & \\
\hline & d. Marjin & $34.400,00$ & 95,56 & $34.400,00$ & 95,56 \\
\hline & e. Keuntungan & $23.407,32$ & 65,02 & $24.113,85$ & 66,98 \\
\hline & Total Marjin & $34.600,00$ & & $34.600,00$ & \\
\hline & Total Keuntungan & $22.983,71$ & & $24.293,52$ & \\
\hline
\end{tabular}

Sumber : Data Primer Diolah September 2006

Keterangan : persentase diperoleh dari perbandingan harga yang diterima oleh konsumen.

Dari Tabel 4 dapat diketahui bahwa peternak sapi perah menjual susu sapi yang dihasilkannya ke pedagang pengumpul dengan harga Rp1.400,00/liter. Sementara itu pedagang pengumpul menjual ke pengolah dengan harga Rp 1.600/liter. Biaya pemasaran yang dikeluarkan oleh pedagang pengumpul I hanya biaya penyusutan 
peralatan sebesar Rp 0,29/liter sedangkan biaya transportasi ditanggung oleh industri pengolah. Untuk pedagang pengumpul II biaya peyusutan peralatan sebesar Rp 0,33/liter dan biaya trasnportasi sebesar Rp 20,00/liter. Total marjin pemasaran yang diperoleh oleh pedagang pengumpul adalah Rp 200,00/liter dan setelah dikurangi dengan biaya pemasaran yang dikeluarkan maka pedagang pengumpul I memperoleh keuntungan sebesar Rp 199,71/liter sedangkan pengumpul II Rp 179,67/liter dari susu yang dipasarkan ke pengolah. Semuanya sama halnya pada saluran pemasaran pada susu pasteurisasi. Pada pengolahan instan susu jahe ini baik pengolah I pada saluran I maupun pengolah II pada saluran II menjual sendiri produknya dengan harga Rp 36.000,00. Pada pengolah I biaya pemasaran yang dikeluarkan adalah untuk pengolahan dan biaya transportasi yang masing-masing nilainya adalah $\mathrm{Rp} 10.952,68$ dan $\mathrm{Rp} 40,00$ dan marjin yang diperoleh sebesar Rp 34.400,00 sehingga keuntungan yang diperoleh adalah sebesar Rp 23.567,03 Pada pengolah II biaya hanya dikeluarkan untuk pengolahan yaitu sebesar Rp 10.286,15 dengan marjin Rp 34.400,00 maka keuntungan yang diperoleh adalah sebesar 24.293,52. Berdasarkan total marjin pemasaran yang terjadi, saluran I dan saluran II memiliki total marjin yang sama yaitu sebesar Rp 34.600,00 atau 96,11\% dari harga yang diterima konsumen. Dari analisis marjin juga dapat dikatakan bahwa sistim pemasaran instan susu jahe dapat dikatakan tidak efisien, karena bagian yang diterima peternak jauh lebih kecil dibandingkan yang diterima lembaga pengolah dimana bagian yang diterima peternak hanya 3,89\% dari harga yang dibayar konsumen sedangkan lembaga pengolah sebesar 95,56 \% dari harga yang dibayar konsumen. Hal ini disebabkan biaya yang dikeluarkan untuk pengolahan yang cukup besar. Perbedaan besarnya bagian harga yang diterima peternak terhadap harga yang dibayar konsumen pada saluran I dan II, tidak berpengaruh terhadap nilai nominal yang diterima peternak karena harga jual yang diterima peternak dari kedua saluran 
pemasaran tersebut sama. Harga susu segar dari peternak di Kecamatan Selupu Rejang dari awal berdirinya industri pengolah susu yaitu awal tahun 2003 terus mengalami kenaikan mulai dari $\quad$ Rp 1.100,00 hingga saat ini Rp 1.400,00 sedangkan ditingkat pengumpul saat ini adalah $\operatorname{Rp} 1.600,00$. Harga ini dapat dikatakan cukup tinggi mengingat pasar susu sapi perah di kecamatan Selupu Rejang ini termasuk pasar oligopsoni dimana hanya terdapat 2 industri pengolah, sehingga peternak hanya bertindak sebagai penerima harga. Namun karena adanya kesepakatan antara peternak dan industri pengolah melalui media koperasi dan Dinas Peternakan sehingga harga yang ditetapkan dapat diterima kedua belah pihak, walaupun sebenarnya bagi peternak harga tersebut belum begitu layak untuk menghasilkan susu dengan kualitas baik karena harga yang diterima peternak tetap tidak mampu untuk membeli konsentrat.

\section{KESIMPULAN DAN SARAN}

\section{Kesimpulan}

Berdasarkan hasil penelitian dan pembahasan, dapat diambil kesimpulan sebagai berikut :

1. Besarnya nilai tambah yang tercipta dari pengolahan susu sapi perah murni menjadi susu pasteurisasi atau susu pasteurisasi adalah sebesar 56,76\% atau Rp 3.949,18/liter bahan baku dan menjadi instan susu jahe sebesar 70,90\% atau Rp 12.762,50/liter bahan baku. Keuntungan yang diperoleh adalah sebesar Rp 3.774,18/liter bahan baku untuk susu pasteurisasi dan Rp 10.829,16/liter bahan baku untuk instan susu jahe.

2. Saluran pemasaran susu sapi perah terdiri dari 2 saluran pemasaran, yaitu : Jalur pemasaran 1 (Peternak - Pengumpul I - Perusahaan Susu Fadhil Jaya Pengecer - Konsumen) dan jalur pemasaran 2 (Peternak - Pengumpul II KOICA Milk Shop - Konsumen). Besarnya marjin pemasaran susu pasteurisasi 
pada saluran I adalah sebesar Rp 6.292,00 atau 81,80 \% dari harga yang dibayar konsumen dan pada saluran 2 sebesar Rp 6.600,00 atau 82,50 \% dari harga yang dibayar konsumen dan marjin pemasaran instan susu jahe pada saluran I dan saluran II adalah sebesar Rp 34.600,00 atau 96,11\% .

\section{Saran}

Industri Pengolahan Susu (IPS) di kecamatan Selupu Rejang mengolah susu sapi peternak hanya pada pagi hari sedangkan hasil pemerahan pada sore hari tidak dimanfaatkan oleh peternak untuk menambah pendapatannya.Peternak sebaiknya mencoba mengolah sendiri hasil produksi sapi perahnya sehingga tidak terlalu tergantung kepada IPS. Apabila pemerintah dapat memberikan bantuan tambahan jumlah sapi perah pada masyarakat sebaiknya juga memberikan bantuan kepada Industri Pengolahan Susu (IPS) agar dapat menambah kapasitas produksinya sehingga hasil produksi sapi dari peternak dapat ditampung lebih banyak sehingga eksistensi peternakan sapi perah di Propinsi Bengkulu dapat dikembangkan dan dipertahankan, khususnya sebagai pendukung penetapan Kabupaten Rejang Lebong sebagai kawasan Agropolitan di Provinsi Bengkulu.

\section{DAFTAR PUSTAKA}

Anonim. 2006 Laporan Kependudukan kecamatan Selupu Rejang. Kecamatan Selupu Rejang: Bengkulu.

Daryanto, Arief. 2006. Persusuan Indonesia : Kondisi Permasalahan. http://www.mma.ipb.ac.id/today/artikel vicco.html. 29 juni 2006

Efriani, Susi. 2003. Analisis Produksi, Pendapatan dan Nilai Tambah Agroindustri Jahe Instan di Bengkulu Selatan. Skripsi. Fakultas Pertanian. Universitas Bengkulu: Bengkulu (tidak dipublikasikan)

Iskandarsyah, Hakim. A.I. Hasyim. Wijaya.1997. Analisis Usahatani dan Pemasaran Komoditas Kacang Hijau di Kecamatan Pekalongan. Kabupaten Lampung Tengah. Penelitian Pertanian IX(2) : 138-148.

Mubyarto. 1984. Pengantar Ilmu Ekonomi Pertanian. LP3ES: Jakarta. 
Soekartawi. 1995. Agribisnis Teori dan Aplikasinya. CV.Rajawali: Jakarta.

Tohir. 1993. Seuntai Penetahuan Tentang Usahatani Indonesia. Gramedia: Jakarta

Tomi, Samril. 2004. Analisis Pendapatan, Nilai Tambah dan Pemasaran Susu pada Peternakan Sapi Perah di Kecamatan Selupu Rejang kabupaten Rejang Lebong. Skripsi. Fakultas Pertanian. Universitas Bengkulu: Bengkulu (tidak dipublikasikan).

Zakaria, W.A. 2000. Analisis Nilai Tambah Ubi Kayu pada Beberapa Agroindustri Berbasis Ubi Kayu di Propinsi Lampung. Sosial Ekonomi VI(2): 118-125. 